\title{
Getting to Maybe: How the World Is Changed
}

By Frances Westley, Brenda Zimmerman and Michael Patton New York: Random House, 2006

272 pages; US\$34.95 cloth

Reviewed by Anton Hart

Publisher and CEO, Longwoods Publishing Corporation

Getting to Maybe promises to make us effective agents of change by telling us how to improve the world by applying the science and process of social innovation.

The book begins with a brief story about Bob Geldof's historic response to the famine in Ethiopia. Here is a little-known musician who created a highly successful global initiative - the Live Aid Telethon - to raise awareness and money. This venture was about

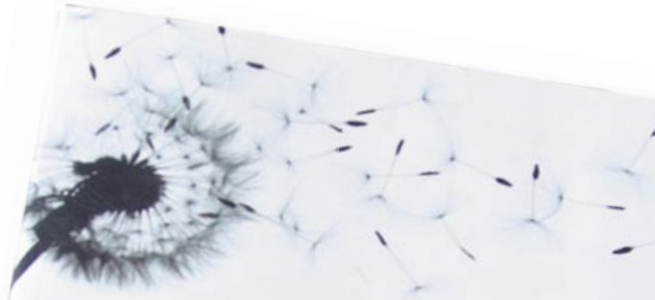
the power of one.

The authors then describe a movement of multiple interactions that took Brazil from a very high infection rate for HIV/AIDS to a very low rate. No one leader could be identified. 
Getting to Maybe analyzes how such changes happen and tries to answer the question, "How can the impossible become possible?" But the title of the book gives the authors away: there isn't an answer. The authors say that "there is no road map for social innovation; it is not a route that can be mapped step by step." Darned. Yet, the book talks about vision, a sense of calling, developing possibilities and the need for intense interactions, networking and information exchange. These factors, mixed with talent and skill in identifying and removing barriers, the authors say, will get you to "maybe."

I am not so sure. For example, by reading about the post-World War II Dutch emigration movement, I was shown a direct path of social innovation that was repeated family after family and year after year. The book To All My Children, by Albert Van der Mey (Paideia Press), demonstrates emigrants' motivations, their often uninhabitable beginnings, their resolve to build a better life, their commitment to community and social fabric and their passion and resolve. These qualities were the foundation of their economic and social success that evolved not many years later. There was a clear path, one often repeated by subsequent waves of immigrants. There was no maybe.

The authors get to "maybe" because that, it appears, is what they set out to do. If they had developed these themes and taken some risks, they might have presented a road map, a strategy and perhaps even a blueprint.

Yet, the many stories about social entrepreneurs are worth reading and serve to inspire those who have the vision. If anything, the reader will understand the importance of identifying roadblocks and reframing these as opportunities. This approach, of course, is not unique to social innovation.

The book is worthwhile, if only to read and re-read a short section on the objective of introducing patient-centred care. It quotes Dr. Don Berwick - CEO of the Institute of Healthcare Improvement and a Harvard professor - describing the treatment of a patient who, he says, is no fool and has a lot to contribute to his own care - if the system would let him. Find out how the patient is patronized, kept in the dark, fed strange foods and pretty much ignored as his care providers do everything to him and never with him. This situation is a problem that can be restated as an opportunity, and so become the impetus to design much-improved patient-centred care, with or without IT.

And if you do not know the story of Linda Lundström (and others like her), read the book. Ms. Lundström designs and makes women's clothing. She grew up in a community that included many First Nation families. When as a youngster 
she was faced by the reality of racism, she was moved to act. She returned to her hometown and applied her knowledge, skill and drive to engage the women and children, to offer hope and opportunity. This is the beginning of social transformation. As I write this, Ms. Lundström is facing her own challenges in dealing with the globalization of the fashion industry. In some form, she will re-emerge; just read the back of every price tag attached to her products: "I have a strong belief in the power of positive energy that all women are capable of radiating towards those we know, each other and the rest of the world."

It is the stories in this book that work. The social entrepreneurs profiled provide the learning and the motivation. They are inspiring.

\section{A post-note: How to change the world}

If you are interested in social entrepreneurs, find a copy of How to Change the World: Social Entrepreneurs and the Power of New Ideas, by David Bornstein (Oxford 2004). The author is a compelling writer who has travelled around the globe to give readers a glimpse of individuals and movements that have changed the world. The stories he has selected are captivating. For example, he describes how Florence Nightingale was motivated by inexplicable obsession, action and orientation for growth with an unwavering belief in the rightness of her ideas - and so she was well suited to apply concentrated focus, practical creativity and long-term energy to advance system change.

Bornstein also writes about child protection in India, assisted living in Hungary, reforming healthcare in Brazil, care of AIDS patients in South Africa, micro credit and the Grameen Bank and the Child Survival Revolution attributed to James Grant, who headed UNICEF from 1980 to 1995.

At the end, Bornstein lists six qualities of successful social entrepreneurs, a blueprint that does not explain why people become social entrepreneurs but does make identifying them possible. And look, he says, at Changemakers.net, an initiative of Ashoka: Innovators for the Public, which focuses on the rapidly growing world of social innovation. It provides solutions and resources needed to help everyone become a "changemaker" and presents compelling stories that explore the fundamental principles of successful social innovation around the world. 